\title{
The effect of a peptide-containing synthetic lung surfactant on gas exchange and lung mechanics in a rabbit model of surfactant depletion
}

This article was published in the following Dove Press journal:

Drug Design, Development and Therapy

8 March 2013

Number of times this article has been viewed

\author{
Johann M van Zyl' \\ Johan Smith ${ }^{2}$ \\ Arthur Hawtrey' \\ 'Division of Pharmacology, \\ ${ }^{2}$ Department of Paediatrics and \\ Child Health, Stellenbosch University, \\ Cape Town, South Africa
}

Background: Currently, a new generation of synthetic pulmonary surfactants is being developed that may eventually replace animal-derived surfactants used in the treatment of respiratory distress syndrome. Enlightened by this, we prepared a synthetic peptide-containing surfactant (Synsurf) consisting of phospholipids and poly-L-lysine electrostatically bonded to poly-L-glutamic acid. Our objective in this study was to investigate if bronchoalveolar lavage (BAL)-induced acute lung injury and surfactant deficiency with accompanying hypoxemia and increased alveolar and physiological dead space is restored to its prelavage condition by surfactant replacement with Synsurf, a generic prepared Exosurf, and a generic Exosurf containing $\mathrm{Ca}^{2+}$.

Methods: Twelve adult New Zealand white rabbits receiving conventional mechanical ventilation underwent repeated BAL to create acute lung injury and surfactant-deficient lung disease. Synthetic surfactants were then administered and their effects assessed at specified time points over 5 hours. The variables assessed before and after lavage and surfactant treatment included alveolar and physiological dead space, dead space/tidal volume ratio, arterial end-tidal carbon dioxide tension $\left(\mathrm{PCO}_{2}\right)$ difference (mainstream capnography), arterial blood gas analysis, calculated shunt, and oxygen ratios.

Results: BAL led to acute lung injury characterized by an increasing arterial $\mathrm{PCO}_{2}$ and a simultaneous increase of alveolar and physiological dead space/tidal volume ratio with no intergroup differences. Arterial end-tidal $\mathrm{PCO}_{2}$ and dead space/tidal volume ratio correlated in the Synsurf, generic Exosurf and generic Exosurf containing $\mathrm{Ca}^{2+}$ groups. A significant and sustained improvement in systemic oxygenation occurred from time point 180 minutes onward in animals treated with Synsurf compared to the other two groups $(P<0.001)$. A statistically significant decrease in pulmonary shunt $(P<0.001)$ was found for the Synsurf-treated group of animals, as well as radiographic improvement in three out of four animals in that group.

Conclusion: In general, surfactant-replacement therapy in the animals did not fully restore the lung to its prelavage condition. However, our data show that the formulated surfactant Synsurf improves oxygenation by lowering pulmonary shunt.

Keywords: pulmonary surfactant, synthetic peptides, respiratory dead space, capnometry, pulmonary gas exchange, oxygenation

\section{Introduction}

Surfactant-replacement therapy with animal-derived surfactant preparations is an established treatment modality for respiratory distress syndrome that revolutionized the care of preterm babies in intensive care units. ${ }^{1,2}$ Pulmonary surfactant is a complex mixture of phospholipids and at least four apoproteins that reduces surface tension at the alveolar surface. ${ }^{3}$ The mixture has unique spreading properties, promotes lung expansion during inspiration, and prevents lung collapse during
Division of Pharmacology, Department of Medicine, Faculty of Medicine and Health Sciences, Stellenbosch University, PO Box 19063, Tygerberg, Cape Town 7505, South Africa

$\mathrm{Tel}+27219389344$

Fax +27 21 9326958

Email jmvzyl@sun.ac.za 
expiration. Of all the protein components in the mixture, the hydrophobic surfactant proteins B (SP-B) and C (SP-C) have an essential function in the spreading, adsorption, and stability of surfactant lipids. ${ }^{4-6}$

Over the past decade, natural and synthetic surfactants have extensively been tested with regard to their in vitro properties and in vivo physiologic effects. ${ }^{1}$ Unfortunately, synthetic products have lost popularity in favor of natural products that contain low concentrations of SP-B and SP-C, which are essential for adsorption and spreading of the surfactant film at the air-liquid interface. However, commercially the large-scale production and supply of natural surfactants are not only time-consuming and expensive with a limited supply, but there are concerns about the reproducibility and purity and the possibility of transmission of infectious material. ${ }^{7}$ The development of an effective artificial surfactant mixture, devoid of foreign protein, that can be prepared in large quantities at a reasonable cost remains challenging. Moreover, a common denominator in acute lung diseases is inactivation of surfactant by plasma and other components. Much work is therefore aimed at constructing a new generation of synthetic surfactants that will be more resistant towards inactivation.

Various research groups have chemically prepared peptides with amino acid sequences based on that of SP-B. In two such studies, the treatment of preterm infant rhesus monkeys and human infants with respiratory distress syndrome was demonstrated with a peptide/phospholipid mixture ( $\mathrm{KL}_{4}$-surfactant). ${ }^{8,9}$ In both studies, this synthetic surfactant expanded the pulmonary alveoli and promoted gas exchange. Based on such a design, we prepared a surfactant consisting of the phospholipids dipalmitoylphosphatidylcholine (DPPC), phosphatidylglycerol (PG), and two polymers: poly-L-lysine electrostatically complexed with poly-L-glutamic acid (Synsurf [S]). The polymers were added to the phospholipids, in order to mimic the hydrophobic and hydrophilic nature of SP-B in the mixture.

In this study, we were particularly interested to compare the efficacy of $\mathrm{S}$ as a synthetic surfactant in a comparative study with a previously used synthetic protein-free surfactant, Exosurf Neonatal ${ }^{10,11}$ (we prepared a generic version), hereafter named GE. Although similar in chemical composition, we cannot guarantee that the GE used in our experiments was identical to commercially manufactured Exosurf Neonatal, as it was discontinued at the time of the present study. However, in a previous study ${ }^{12}$ before its discontinuation, we were able to compare the in vivo efficacy of our GE and its physiological effects and gas-exchange capabilities with the then-available commercial Exosurf Neonatal product. Although we found differences that we could not provide plausible explanations for in the on-site formulations, the overall outcome in performance was similar to Exosurf Neonatal. Moreover, the surface tension-lowering ability of the GE preparations were not significantly different to that of Exosurf Neonatal when we tested them. ${ }^{13}$ In the present study, we also found that the surface-lowering ability of GE and $\mathrm{S}$ is virtually similar. Although surface-tension measurements strongly depend on the technique applied, our data, measured under dynamic conditions, are in agreement with the less effective surface tension-lowering ability reported by others in the absence of SP-B and SP-C. ${ }^{14}$

Considering reports in literature ${ }^{15,16}$ that bivalent cations such as $\mathrm{Ca}^{2+}$ can increase the speed of surface adsorption of surfactant molecules and to stabilize films in experimental conditions, we decided to include a GE preparation mixed with $\mathrm{Ca}^{2+}\left(\mathrm{GE}_{\mathrm{Ca}}{ }^{2+}\right)$ to elucidate the beneficial effect. Hence we tested the efficacy of three surfactant preparations in an adult rabbit model with acute lung injury and surfactant deficiency. We tested the hypothesis that a synthetic peptide-containing surfactant (S) would improve systemic oxygenation and restore the surfactant-deficient lungs to prelavage condition after surfactant depletion was induced by repeated bronchoalveolar lavage (BAL) in comparison to two synthetic surfactants devoid of protein.

\section{Materials and methods}

DPPC was obtained from Avanti Polar Lipids (Alabaster, AL, USA). PG, cetyl alcohol, tyloxapol, poly-L-lysine (molecular weight $16.1 \mathrm{kDa}$ ) and poly-L-glutamic acid (molecular weight $12 \mathrm{kDa}$ ) were purchased from Sigma-Aldrich (St Louis, MO, USA). Phospholipid purity was verified by thin-layer chromatography. ${ }^{17}$ Sterile water for injection was used in the preparation of surfactant. Chloroform used was high-performance liquid chromatography-grade (Merck, Darmstadt, Germany).

\section{Experimental surfactant preparations}

Synsurf (S) was prepared by mixing DPPC, hexadecanol, and $\mathrm{PG}$ in a 10:1.1:1 ratio $(\mathrm{w} / \mathrm{w})$ in chloroform. The organic solvent was then removed by rotary evaporation and the mixture was dried under a continuous stream of nitrogen at room temperature. Poly-L-lysine ( 100-120 residues) was mixed with poly-L-glutamate (approximately 80 residues) and incubated at $37^{\circ} \mathrm{C}$ in $0.1 \mathrm{M} \mathrm{NaCl}$ to give a complex that was $50 \%$ neutralized. The complex was prepared in such a manner as to be positively charged through having an excess 
of poly-L-lysine residues. The dried phospholipid film was then hydrated with the polymer mixture $(3 \%$ by weight of the phospholipid concentration) and gently mixed in the presence of glass beads. A Branson (Danbury, CT, USA) B-15P ultrasonicater fitted with a microtip was then used to sonicate the mixture on ice under a stream of nitrogen (power of 20 watts for $7 \times 13$ seconds; 60 -second intervals). Hereafter, $24 \mathrm{mg}$ of tyloxapol was added to the preparation, and the tube was sealed under nitrogen before use. The GE surfactant was also prepared in a similar fashion as described above and consisted of three components: DPPC/ hexadecanol/tyloxapol (13.5:1.5:1) in $0.1 \mathrm{M} \mathrm{NaCl}$. The dose of $\mathrm{S}, \mathrm{GE}$, and $\mathrm{GE}_{\mathrm{Ca}}{ }^{2+}$ used was $100 \mathrm{mg} / \mathrm{kg}$. $\mathrm{CaCl}_{2}$ included in $\mathrm{GE}_{\mathrm{Ca}}{ }^{2+}$ amounted to $5 \mathrm{mM}$.

\section{Animal preparation}

Animal care and experimental procedures were performed under approval from the Faculty of Health Sciences Research Committee of Stellenbosch University. Adult New Zealand white rabbits weighing $2.5-3.75 \mathrm{~kg} \pm 0.39 \mathrm{~kg}$ were premedicated with ketamine $(25-50 \mathrm{mg} / \mathrm{kg})$. They were positioned on their back and kept in this position throughout the experiment. An auricular intravenous line was inserted, and an infusion ( $5 \mathrm{~mL} / \mathrm{kg} /$ hour) with a Ringer's glucose solution started. Animals then underwent tracheostomy, and an uncuffed endotracheal tube (size 2.5-4.0 $\mathrm{mm}$ ) was inserted and firmly tied to exclude air leaks. Intravenous pentobarbital $(6 \mathrm{mg} / \mathrm{kg}$ body weight) and pancuronium bromide $(0.1 \mathrm{mg} / \mathrm{kg}$ body weight) were administered. Anesthesia was maintained with an infusion of sodium pentobarbital at a dose of $6 \mathrm{mg} / \mathrm{kg} / \mathrm{hour}$. The left carotid artery was catheterized for arterial blood gas measurements and hemodynamic monitoring (blood pressure and pulse rate). Lidocaine (1\%) was used for local anesthesia at surgical sites. Animals were ventilated using the time-cycled pressurelimited mode (Julian Anaesthetic Workstation; Dräger, Lübeck, Germany) at a peak inspiratory pressure necessary to maintain a tidal volume $\left(\mathrm{V}_{\mathrm{T}}\right)$ of $10 \mathrm{~mL} / \mathrm{kg}$ and partial pressure of carbon dioxide in arterial blood $\left(\mathrm{PaCO}_{2}\right)$ between 4 and $7.5 \mathrm{kPa}$ (30-56 mmHg). The $\mathrm{V}_{\mathrm{T}}$ of a spontaneously breathing young adult rabbit $(2.775 \pm 0.198 \mathrm{~kg})$ varies between 19 and $25 \mathrm{~mL}$, and the mean $\mathrm{PaCO}_{2}$ for rabbits weighing 2.9-3.5 kg (in the absence of ketamine) is $31.8 \pm 1.7 \mathrm{mmHg}(4.2 \pm 0.22 \mathrm{kPa}) .^{18,19}$ Using the same model, $\mathrm{V}_{\mathrm{T}}$ varying between 8 and $12 \mathrm{~mL} / \mathrm{kg}$ resulting in partial arterial pressure of $\mathrm{CO}_{2}$ between 4.5 and $5.3 \mathrm{kPa}$ have been reported. ${ }^{20-22}$ However, since a body of researchers used $\mathrm{V}_{\mathrm{T}}$ of $10 \mathrm{~mL} / \mathrm{kg}$ in adult rabbits, we decided to standardize our protocol accordingly. ${ }^{23-27}$ This $\mathrm{V}_{\mathrm{T}}$ was verified by a combined neonatal $\mathrm{CO}_{2} /$ flow sensor $\left(\mathrm{CO}_{2} \mathrm{SMO}\right.$ plus respiratory profile monitor model 8000; Novametrix Medical Systems, Wallingford, CT, USA). At the moment of the incision of the trachea, continuous intravenous infusion of pentobarbital sodium was commenced (6 mg/kg/hour). Neuromuscular paralysis was achieved by administering intravenous pancuronium bromide $(0.1 \mathrm{mg} / \mathrm{kg})$ on an hourly basis. The rectal temperature was monitored, and the aim was to keep it between $38^{\circ} \mathrm{C}$ and $40^{\circ} \mathrm{C}$ with an electrical heating pad. The reported normal range of rectal temperatures in the rabbit is $38.6^{\circ} \mathrm{C}-40.1^{\circ} \mathrm{C} .{ }^{19}$ The blood pressure transducer was intermittently flushed with saline containing heparin 5 IU heparin $/ \mathrm{mL}$. The blood pressure of the healthy rabbit varies between 90-130 (systolic) and 60-91 (diastolic) mmHg. ${ }^{19}$ The depth of anesthesia was intermittently checked by pinching the web of a hind-leg paw to create a painful stimulus, and by the flow sensor to check for spontaneous breathing efforts. The study lasted 5 hours before the animals were killed by a lethal intra-arterial injection of $15 \%$ potassium chloride.

\section{Bronchoalveolar lavage and surfactant treatment}

Animals were subjected to repeated warm saline $\left(37^{\circ} \mathrm{C}\right)$ lavage $(20 \mathrm{~mL} / \mathrm{kg})$ via the endotracheal tube, similar to the technique described by Lachmann et al. ${ }^{28}$ Lavage end points included a decrease in arterial oxygen tension $\left(\mathrm{PaO}_{2}\right)$ to below $11 \mathrm{kPa}$ (fraction of inspiratory oxygen $\left[\mathrm{FiO}_{2}\right] 1.0$ ) and a decrease in dynamic respiratory compliance $\left(\mathrm{C}_{\mathrm{dyn}}\right)$ by $40 \%$ or more. The total volume of lavage fluid (corrected for body weight) necessary to achieve significant surfactant deficiency/acute lung injury was recorded together with the volume retrieved. The retrieved volume was expressed as a percentage of the instilled volume. A 10-minute period was allowed for stabilization following lavage, and then animals were randomized into three treatment groups. Group A received the GE protein-free surfactant, group $B$ the GE plus $\mathrm{Ca}^{2+}(5 \mathrm{mM})$, and group $\mathrm{C}$ the peptide-containing surfactant (Synsurf, InnovUS, Stellenbosch University) via the endotracheal tube (DPPC concentration $100 \mathrm{mg} / \mathrm{kg}$ ).

\section{Measurement of lung mechanics, capnometry, and arterial blood gases}

The $\mathrm{FiO}_{2}(1.0), \mathrm{V}_{\mathrm{T}}$ (aim $10 \mathrm{~mL} / \mathrm{kg}$ ), respiratory rate (40 breaths per minute, spontaneous breathing rate of a rabbit varies between 32 and 60/minute), positive end-expiratory pressure (PEEP: $5 \mathrm{cmH}_{2} \mathrm{O}$ after lavage), and the inspiratory time $\left(\mathrm{T}_{\mathrm{I}}\right)$ :expiratory time $\left(\mathrm{T}_{\mathrm{E}}\right)$ at 1:1.5 $\left(\mathrm{T}_{\mathrm{I}} 0.6\right.$ seconds, $\mathrm{T}_{\mathrm{E}} 0.9 \mathrm{sec}-$ onds) were kept constant throughout the study. Arterial blood gases (Radiometer ABL 500 blood gas analyzer; Regent 
Medic, London, UK), pulmonary functions (dynamic expiratory airway resistance $\left.\left[\mathrm{Raw}_{\mathrm{e}}\right], \mathrm{V}_{\mathrm{T}}, \mathrm{C}_{\mathrm{dyn}}\right)$, ventilator settings, physiological parameters (rectal temperature, blood pressure, pulse rate), oxygenation, capnometry, and other calculations were recorded/measured before and after lavage and at 15, 30, $60,90,120,180,240$, and 300 minutes after surfactantreplacement therapy. Oxygenation variables were calculated. The arterial/alveolar $(\mathrm{a} / \mathrm{A})$ ratio $=\mathrm{PaO}_{2} /\left(\mathrm{P}_{\mathrm{B}}-47\right) \mathrm{FiO}_{2}-$ $\mathrm{PaCO}_{2} / \mathrm{R}$ ( $\mathrm{R}$ assumed respiratory quotient 0.8 ). Pulmonary function and $\mathrm{CO}_{2}$ measurements were measured with the $\mathrm{CO}_{2} \mathrm{SMO}$ Plus respiratory profile monitor. The low deadspace measurement chamber with flow sensor was placed inbetween the ventilator circuit wye and endotracheal tube adaptor. The $\mathrm{CO}_{2} \mathrm{SMO}$ Plus monitor measures and displays respiratory mechanics and carbon dioxide data and calculates flow, $\mathrm{CO}_{2}$, and oximetry-related parameters. Flow-sensor calibration was not necessary, since the device automatically zeroed periodically by internal values. Partial pressure of end-tidal carbon dioxide tension $\left(\mathrm{PET}_{\mathrm{CO} 2}\right)$ was measured by mainstream infrared absorption. By using the tension of carbon dioxide $\left(\mathrm{PCO}_{2}\right)$ and volume measurements, the anatomic dead space, alveolar dead space $\left(\mathrm{V}_{\text {Dalv }}\right)$, physiological dead space, physiological dead space $/ \mathrm{V}_{\mathrm{T}}$ ratio, and $\mathrm{V}_{\text {Dalv }} / \mathrm{V}_{\mathrm{T}}$ ratio were determined. The arterial end-tidal $\mathrm{PCO}_{2}$ difference $\left(\mathrm{P}[\mathrm{a}-\mathrm{et}] \mathrm{CO}_{2}\right)$ was obtained by subtracting the $\mathrm{PetCO}_{2}$ from $\mathrm{PaCO}_{2}$ of an arterial blood gas sample. The shunt was calculated as follows: $\mathrm{Q}_{\mathrm{s}} / \mathrm{Q}_{\mathrm{t}}=88.77-2.4\left(20.4 \log \mathrm{PaO}_{2} / \mathrm{FiO}_{2}\right) .{ }^{29}$

\section{Chest radiography}

Anteroposterior chest radiographs were taken prior to lavage, immediately prior to randomization, and at the end of the study. The distance between the probe and film was kept at $24 \mathrm{~cm}$. Changes in lung fields were assessed in a blinded manner in regard to whether the radiographic opacification following lavage (atelectasis) resolved (better), remained unchanged (similar), or deteriorated (worse).

\section{Statistical methods}

One-way analysis of variance and linear mixed-effects modeling were used as described by Pinheiro et $\mathrm{al}^{30}$ and Maritz et al. ${ }^{31}$ Variables measured for groups at the predetermined time points were also compared using unpaired $t$-tests. For continuous variables measured over time, a linear regression of the variables over time by least-squares analysis was used to compare groups by differences in the initial responses to surfactant ( $y$-intercepts) and change over time (slopes). Data are expressed as means \pm standard deviation. A $P$-value $<0.05$ was taken as significant (Statistica version 10;
StatSoft, Tulsa, OK, USA). GraphPad (La Jolla, CA, USA)

Prism 5 was used to determine correlations.

\section{Results}

\section{Baseline characteristics}

The mean ( \pm standard deviation) values for weight and prelavage mean arterial blood pressure, arterial blood gases, capnometry, and pulmonary functions are shown in Table 1. The total volume of lavage fluid required to induce acute

Table I Results before bronchoalveolar lavage at 3 hours and 5 hours after surfactant treatment in twelve rabbits

\begin{tabular}{|c|c|c|c|}
\hline Variable & $\begin{array}{l}\text { Synsurf group } \\
(n=4)\end{array}$ & $\begin{array}{l}\text { Exosurf group } \\
(n=4)\end{array}$ & $\begin{array}{l}\text { Exosurf }+\mathrm{Ca}^{2+} \\
\text { group }(n=4)\end{array}$ \\
\hline Weight (kg) & $3.13 \pm 0.56$ & $2.95 \pm 0.19$ & $3.44 \pm 0.24$ \\
\hline Pre- $\mathrm{V}_{\mathrm{T}}(\mathrm{mL} / \mathrm{kg})$ & $10.08 \pm 0.29$ & $10.20 \pm 0.58$ & $10.03 \pm 0.35$ \\
\hline 180 minutes & $10.08 \pm 0.17$ & $9.85 \pm 0.21$ & $10.13 \pm 0.19$ \\
\hline 300 minutes & $10.05 \pm 0.10$ & $9.75 \pm 0.24$ & $9.93 \pm 0.22$ \\
\hline $\begin{array}{l}\text { Pre-MABP } \\
(\mathrm{mmHg})\end{array}$ & $82.60 \pm 4.07$ & $92.40 \pm 3.83$ & $91.50 \pm 7.51$ \\
\hline 180 minutes & $89.50 \pm 11.21$ & $100.30 \pm 6.99$ & $93.25 \pm 4.72$ \\
\hline 300 minutes & $87.00 \pm 15.12$ & $96.75 \pm 12.2$ & $91.00 \pm 14.67$ \\
\hline $\begin{array}{l}\text { Pre- } \mathrm{PaO}{ }_{2} \\
(\mathrm{mmHg})\end{array}$ & $499.70 \pm 9.46$ & $511.10 \pm 17.38$ & $509.30 \pm 24.08$ \\
\hline Post- & $57.95 \pm 14.90$ & $53.25 \pm 15.97$ & $50.81 \pm 18.30$ \\
\hline 180 minutes & $152.30 \pm 49.27$ & $85.69 \pm 25.85$ & $109.90 \pm 46.32$ \\
\hline 300 minutes & $281.30 \pm 47.64$ & $74.25 \pm 8.84$ & $85.69 \pm 32.56$ \\
\hline Pre-a/A ratio & $0.76 \pm 0.02$ & $0.77 \pm 0.04$ & $0.76 \pm 0.03$ \\
\hline Post- & $0.09 \pm 0.02$ & $0.08 \pm 0.02$ & $0.08 \pm 0.03$ \\
\hline 180 minutes & $0.23 \pm 0.07$ & $0.13 \pm 0.04$ & $0.16 \pm 0.07$ \\
\hline 300 minutes & $0.42 \pm 0.07$ & $0.11 \pm 0.01$ & $0.13 \pm 0.05$ \\
\hline $\begin{array}{l}\text { Pre-PaCO } \\
(\mathrm{mmHg})\end{array}$ & $40.69 \pm 3.15$ & $39.38 \pm 6.26$ & $36.19 \pm 8.04$ \\
\hline 180 minutes & $38.44 \pm 4.99$ & $38.63 \pm 5.49$ & $36.19 \pm 4.99$ \\
\hline 300 minutes & $36.75 \pm 2.12$ & $40.13 \pm 4.18$ & $38.81 \pm 7.15$ \\
\hline $\begin{array}{l}\text { Pre-PetCO } \\
(\mathrm{mmHg})\end{array}$ & $14.25 \pm 3.06$ & $14.63 \pm 3.09$ & $13.88 \pm 1.3$ \\
\hline 180 minutes & $9.56 \pm 1.88$ & $10.13 \pm 2.17$ & $10.69 \pm 0.94$ \\
\hline 300 minutes & $9.75 \pm 1.50$ & $9.38 \pm 1.44$ & $9.75 \pm 2.21$ \\
\hline $\begin{array}{l}\text { Pre-P(a-et) } \mathrm{CO}_{2} \\
(\mathrm{mmHg})\end{array}$ & $26.44 \pm 4.95$ & $24.75 \pm 6.15$ & 22. $31 \pm 7.07$ \\
\hline Postlavage & $43.50 \pm 15.16$ & $42.66 \pm 8.67$ & $42.88 \pm 15.07$ \\
\hline 300 minutes & $27.00 \pm 2.60$ & $30.75 \pm 3.06$ & $29.06 \pm 8.58$ \\
\hline \multicolumn{4}{|l|}{$\begin{array}{l}\mathrm{C}_{\text {dyn }}(\mathrm{mL} / \mathrm{cm} \\
\left.\mathrm{H}_{2} \mathrm{O} / \mathrm{kg}\right)\end{array}$} \\
\hline Prelavage & $0.93 \pm 0.16$ & $0.98 \pm 0.16$ & $0.88 \pm 0.17$ \\
\hline Postlavage & $0.47 \pm 0.04$ & $0.46 \pm 0.05$ & $0.42 \pm 0.06$ \\
\hline 300 minutes & $0.47 \pm 0.01$ & $0.42 \pm 0.02$ & $0.44 \pm 0.06$ \\
\hline \multicolumn{4}{|l|}{$\operatorname{Raw}_{\mathrm{e}}$} \\
\hline Prelavage & $33.75 \pm 3.59$ & $45.25 \pm 24.06$ & $36.75 \pm 11.03$ \\
\hline Postlavage & $53.50 \pm 4.20$ & $74.25 \pm 25.93$ & $59.25 \pm 13.07$ \\
\hline 300 minutes & $46.75 \pm 11.33$ & $72.00 \pm 22.32$ & $55.25 \pm 9.85$ \\
\hline
\end{tabular}

Note: Data are shown as the means \pm standard deviation.

Abbreviations: $\mathrm{V}_{\mathrm{T}}$, tidal volume; $\mathrm{MABP}$, mean arterial blood pressure; $\mathrm{PaO}_{2}$, arterial $\mathrm{PO}_{2} ; \mathrm{PAO}_{2}$, alveolar $\mathrm{PO}_{2} ; \mathrm{PaCO}_{2}$, arterial $\mathrm{PCO}_{2} ; \mathrm{PetCO}_{2}$, end-tidal $\mathrm{PCO}_{2} ; \mathrm{P}$ (a-et) $\mathrm{CO}_{2}$, arterial end-tidal $\mathrm{PCO}_{2}$; Raw $\mathrm{e}_{\mathrm{e}}$, expiratory airway resistance; $\mathrm{C}_{\mathrm{dyn}}$, dynamic respiratory compliance; a/A ratio, arterial/alveolar ratio. 
lung injury and surfactant deficiency (S 74.75 $\pm 17.04 \mathrm{~mL}$, $\mathrm{GE} 73.58 \pm 21.2 \mathrm{~mL}, \mathrm{GE}_{\mathrm{Ca}}{ }^{2+} 73.58 \pm 21.2 \mathrm{~mL}$ ) and the percentage of fluid retrieved from the airways (lavage $\%$ : S 86.5\% \pm 6.73\%; GE 79.38\% $\pm 7.70 \%$; $\mathrm{GE}_{\mathrm{ca}}{ }^{2+}$ $79.25 \% \pm 3.30 \%$ ) did not differ between the groups. The end points of lavage were similar between the groups. Although the aim was to randomize the individual animals 10 minutes after the final lavage and after the chest X-ray was performed, in reality, the randomization occurred at $9 \pm 3.16$ minutes. There were no intergroup differences.

\section{Changes in gas exchange and shunt}

The changes in $\mathrm{PaO}_{2}$ and a/A ratio before and after surfactant treatment are given in Table 1 . The $\mathrm{PaO}_{2}$ and a/A ratio decreased significantly $(P<0.05)$ after lavage. Following treatment with the respective surfactants, the following was noted: oxygenation as reflected by the $\mathrm{PaO}_{2}$ and a/A ratio improved significantly over time in comparison to the postlavage level (time point $0, P<0.05$; Figure 1, A and B). However, significantly better and sustained improvement in systemic oxygenation occurred from baseline at $60 \mathrm{~min}$ utes in the animals treated with $\mathrm{S}(P=0.02)$ compared to the other two groups (global test mixed-effects model $\left.\chi^{2}=58.81, P<0.001\right)$. Improvement in oxygenation was also recorded for the animals treated with $\mathrm{GE}_{\mathrm{Ca}}{ }^{2+}$, but it was significantly less than that recorded in the $\mathrm{S}$ group. A statistically significant decrease in calculated pulmonary shunt (time period 0-300 minutes) was observed in the S-treated group of animals (intergroup differences $\mathrm{S} 31.49 \pm 10.68 \mathrm{vs}$ $\mathrm{GE} 41.13 \pm 1.63, P=0.01$, and $\mathrm{S}$ vs $\mathrm{GE}_{\mathrm{Ca}}{ }^{2+} 37.36 \pm 5.29$, $P=0.002$; Friedman analysis of variance). At 300 minutes, the mean calculated value for $\mathrm{S}$ was $12.03 \%$ versus $32.17 \%$ and $40.33 \%$ for $\mathrm{GE}_{\mathrm{Ca}}{ }^{2+}$ and GE, respectively (Figure 2).

\section{Changes in pulmonary mechanics}

Despite the significant improvement in systemic oxygenation (gas exchange), no real changes in pulmonary mechanics from baseline (time point 0 ) over time were demonstrated. $\mathrm{C}_{\text {dyn }}$ decreased significantly from the prelavage value, and in spite of surfactant treatment decreased nonsignificantly thereafter over time in the three groups (Figure 3). BAL resulted in significant reduction of $\mathrm{C}_{\mathrm{dyn}}$ in all of the rabbits and an increase of $\mathrm{Raw}_{\mathrm{e}}$ by approximately $52 \%, 64 \%$ and $61 \%$, respectively, from baseline (Table 1). After surfactant instillation, no significant changes for these two parameters were observed over time. Capnometry revealed the effects of lavage on dead spaces and the changes in $\mathrm{V}_{\text {Dalv }} / \mathrm{V}_{\mathrm{T}}$ ratio, physiological dead space $/ \mathrm{V}_{\mathrm{T}}$ ratio, $\mathrm{V}_{\text {DPhys }} / \mathrm{V}_{\mathrm{T}}$ ratio and the arterial end-tidal
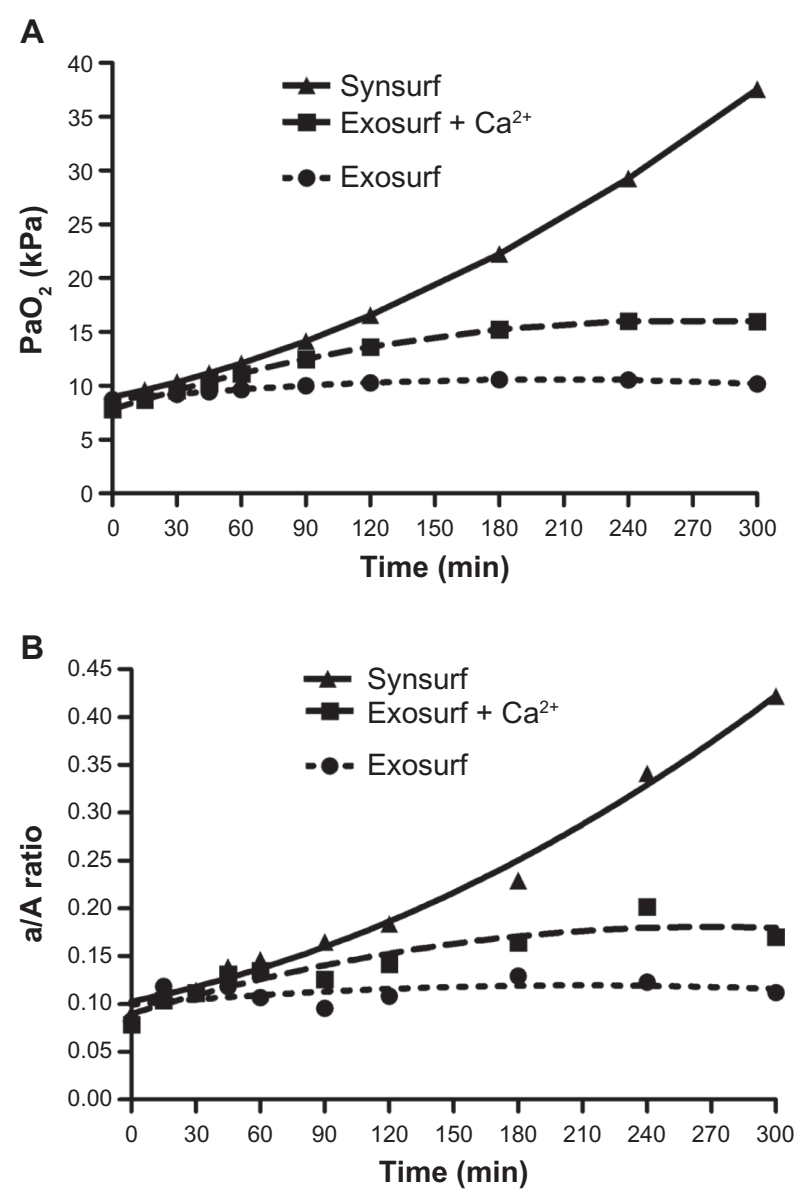

Figure I Time profile for oxygenation in the rabbit groups, as reflected by the arterial $\mathrm{PaO}_{2}$ and a/A ratio after surfactant administration.

Abbreviations: a/A, arterial/alveolar; $\mathrm{PaO}_{2}$, arterial $\mathrm{PO}_{2}$.

$\mathrm{PCO}_{2}$ difference $\mathrm{P}(\mathrm{a}$-et $) \mathrm{CO}_{2}$ before lavage and after surfactant treatment (Table 1 and Figure 4A-C). At randomization (baseline), all of these variables had significantly changed in comparison to the prelavage measurements. In all three groups, the $\mathrm{V}_{\mathrm{D}} / \mathrm{V}_{\mathrm{T}}$ ratio as well as the $\mathrm{V}_{\text {Dalv }} / \mathrm{V}_{\mathrm{T}}$ ratio did not

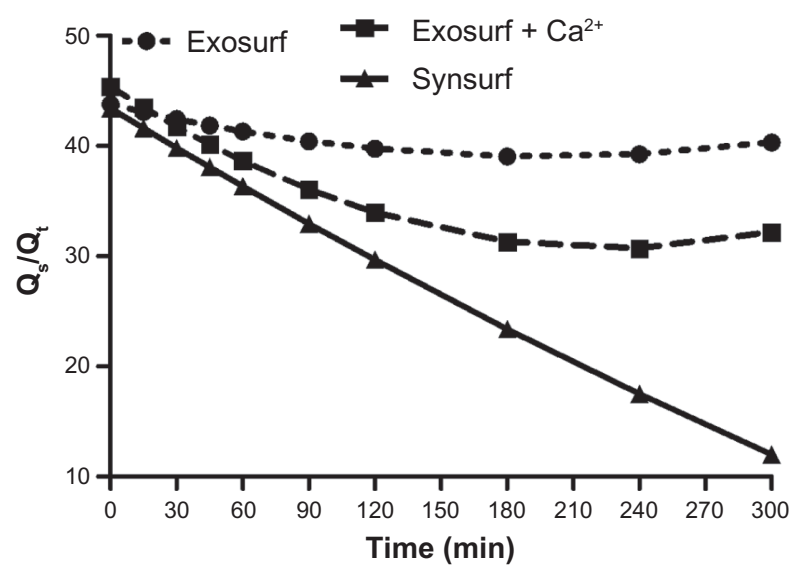

Figure 2 Time profile of pulmonary shunt after administration of surfactant in rabbit groups. 


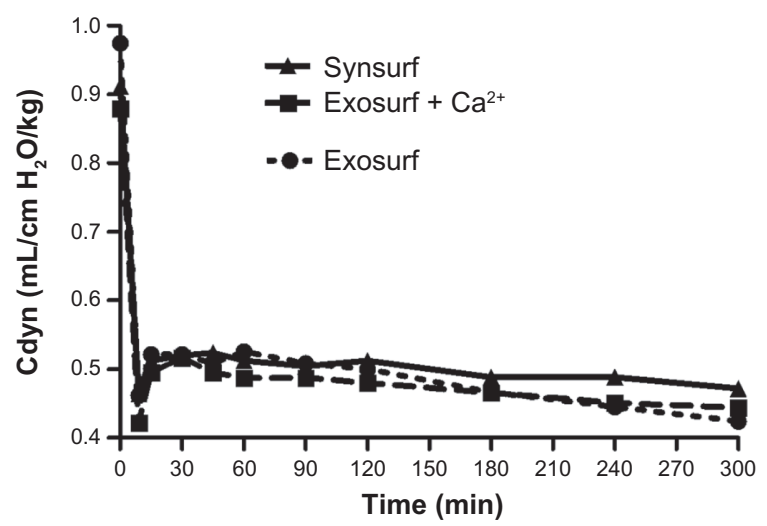

Figure 3 Compliance of the respiratory system: time-profile comparison of rabbit groups prelavage and after surfactant administration.

Abbreviation: $C_{d y n}$, dynamic respiratory compliance.
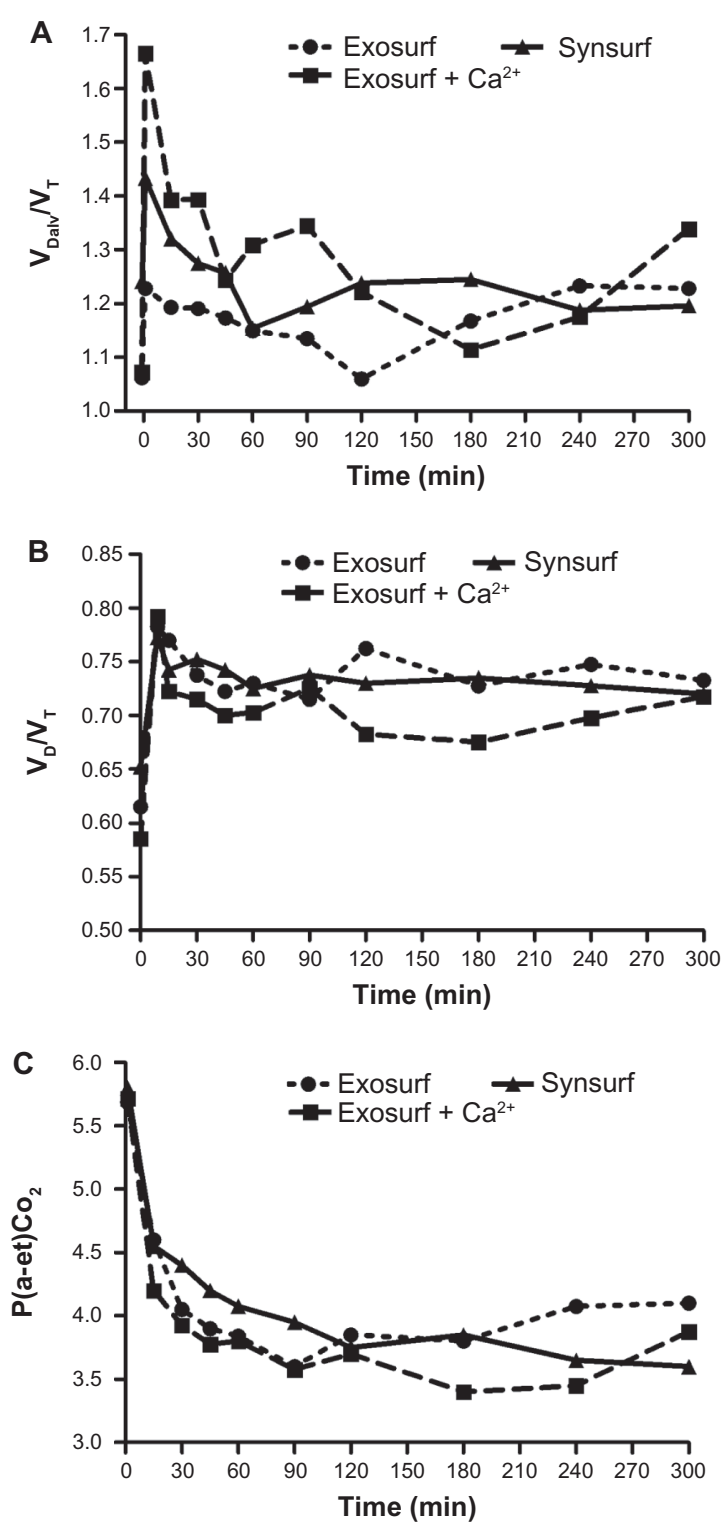

Figure 4 Time profile of (A) alveolar dead space/tidal volume ratio $\left(\mathrm{V}_{\text {Dalv }} / \mathrm{V}_{\mathrm{T}}\right)$, (B) dead space/tidal volume ratio $\left(\mathrm{V}_{\mathrm{D}} / \mathrm{V}_{\mathrm{T}}\right)$, and $(\mathbf{C})$ arterial end-tidal $\mathrm{PCO}_{2}$ difference before and after surfactant administration. change significantly from baseline, despite treatment with surfactant. This finding, together with the increased $\mathrm{P}$ (a-et) $\mathrm{CO}_{2}$, indicates a ventilation-perfusion mismatch.

\section{Correlations}

We found that the best correlation could be calculated between the physiologic dead space and the a/ $\mathrm{A} \mathrm{PO}_{2}$ ratio,

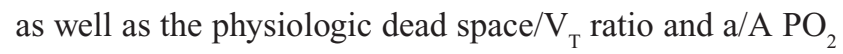
ratio in all three groups of rabbits (Table 2). We also found good correlations between the arterial end-tidal $\mathrm{PCO}_{2}$ and $\mathrm{V}_{\text {Dalv }}$ as well as $\mathrm{V}_{\text {Dalv }} / \mathrm{V}_{\mathrm{T}}$ components in the $\mathrm{S}-$ and $\mathrm{GE}_{\mathrm{Ca}}{ }^{2+}$ treated groups of rabbits (Table 3 ). There was a significant negative correlation between $\mathrm{P}($ a-et $) \mathrm{CO}_{2}$ and $\mathrm{PaO}_{2}$ in S- and $\mathrm{GEca}^{2+}$-treated rabbits $\left(\mathrm{S}, r=-0.65, P=0.044 ; \mathrm{GE}_{\mathrm{Ca}}{ }^{2+}\right.$, $r=-0.74, P=0.014)$ and a significant positive correlation between $\mathrm{P}\left(\mathrm{a}\right.$-et) $\mathrm{CO}_{2}$ and $\mathrm{Q}_{\mathrm{s}} / \mathrm{Q}_{\mathrm{t}}$ in all three groups for shunt percentage above $30 \%(\mathrm{~S}, r=0.86, P=0.0014$; GE, $r=0.92$, $\left.P=0.0002 ; \mathrm{GE}_{\mathrm{Ca}}{ }^{2+}, r=0.91, P=0.0003\right)$.

\section{Radiographic changes}

Radiographic improvement was found in three out of four animals treated with $\mathrm{S}$, in comparison to one out of four rabbits in the $\mathrm{GE}_{\mathrm{Ca}}{ }^{2+}$ group and two out of four in the pure GE-treated rabbit group.

\section{Discussion and conclusions}

By selecting the well-established saline-lavage methodology introduced by Lachmann et al, ${ }^{28}$ we were able to create acute respiratory failure and lung injury with associated surfactant deficiency in adult rabbits. Repeated saline lavage brought about a deterioration in gas exchange, increased dead spaces,

Table 2 Relation between arterial/alveolar $\mathrm{PO}_{2}$ ratio and deadspace components

\begin{tabular}{|c|c|c|c|c|}
\hline \multirow{2}{*}{$\begin{array}{l}\text { Surfactant } \\
\text { group }\end{array}$} & \multirow[t]{2}{*}{ Variable } & \multicolumn{3}{|c|}{ Correlation coefficients } \\
\hline & & $r$ & $r^{2}$ & $P$ \\
\hline \multirow[t]{4}{*}{ Synsurf } & $\mathrm{V}_{\text {Dalv }}$ & 0.37 & 0.13 & 0.2704 \\
\hline & $\mathrm{V}_{\text {Dalv }} / \mathrm{V}_{\mathrm{T}}$ & 0.31 & 0.10 & 0.3510 \\
\hline & $\mathrm{V}_{\mathrm{DP}}$ & 0.94 & 0.88 & 0.0000 \\
\hline & $\mathrm{V}_{\text {Dphys }} / \mathrm{V}_{\mathrm{T}}$ & 0.90 & 0.80 & 0.0001 \\
\hline \multirow[t]{4}{*}{ Exosurf } & $\mathrm{V}_{\text {Dalv }}$ & 0.49 & 0.24 & 0.0928 \\
\hline & $\mathrm{V}_{\text {Dalv }} / \mathrm{V}_{\mathrm{T}}$ & 0.31 & 0.10 & 0.2675 \\
\hline & $\mathrm{V}_{\text {Dphys }}$ & 0.93 & 0.86 & 0.0000 \\
\hline & $\mathrm{V}_{\text {Dphys }} / \mathrm{V}_{\mathrm{T}}$ & 0.93 & 0.86 & 0.0000 \\
\hline \multirow[t]{4}{*}{ Exosurf $+\mathrm{Ca}^{2+}$} & $\mathrm{V}_{\text {Dalv }}$ & 0.60 & 0.36 & 0.0497 \\
\hline & $\mathrm{V}_{\text {Dalv }} / \mathrm{V}_{\mathrm{T}}$ & 0.58 & 0.33 & 0.0307 \\
\hline & $\mathrm{V}_{\text {Dphys }}$ & 0.85 & 0.72 & 0.0006 \\
\hline & $\mathrm{V}_{\text {Dphys }}^{\text {Dphys }} / \mathrm{V}_{\mathrm{T}}$ & 0.83 & 0.69 & 0.0009 \\
\hline
\end{tabular}

Abbreviations: $\mathrm{V}_{\text {Dalv }}$ alveolar dead space; $\mathrm{V}_{\text {Dalv }} / \mathrm{V}_{\mathrm{T}}$, alveolar dead-space/tidal volume ratio; $V_{\text {Dphys }}$, physiologic dead space; $V_{\text {Dphys }} / V_{T}$, physiologic dead space/tidal volume ratio. 
Table 3 Relation between arterial end-tidal $\mathrm{PCO}_{2}$ difference and dead-space components

\begin{tabular}{lllll}
\hline Surfactant & Variable & \multicolumn{3}{c}{ Correlation coefficients } \\
\cline { 3 - 5 } group & & $\boldsymbol{r}$ & $\boldsymbol{r}^{2}$ & $\boldsymbol{P}$ \\
\hline Synsurf & $\mathrm{V}_{\text {Dalv }}$ & 0.88 & 0.78 & 0.0004 \\
& $\mathrm{~V}_{\text {Dalv }} / \mathrm{V}_{\mathrm{T}}$ & 0.87 & 0.75 & 0.0005 \\
& $\mathrm{~V}_{\text {Dphys }}$ & 0.63 & 0.40 & 0.0382 \\
& $\mathrm{~V}_{\text {Dphys }} / \mathrm{V}_{\mathrm{T}}$ & 0.70 & 0.49 & 0.0172 \\
Exosurf & $\mathrm{V}_{\text {Dalv }}$ & 0.74 & 0.54 & 0.0096 \\
& $\mathrm{~V}_{\text {Dalv }} / \mathrm{V}_{\mathrm{T}}$ & 0.19 & 0.04 & 0.5788 \\
& $\mathrm{~V}_{\text {Dphys }}$ & $0.5 \mathrm{I}$ & 0.26 & $0.107 \mathrm{I}$ \\
& $\mathrm{V}_{\text {Dhhys }} / \mathrm{V}_{\mathrm{T}}$ & 0.35 & 0.13 & $0.286 \mathrm{I}$ \\
Exosurf $+\mathrm{Ca}^{2+}$ & $\mathrm{V}_{\text {Dalv }}$ & 0.90 & $0.8 \mathrm{I}$ & 0.0002 \\
& $\mathrm{~V}_{\text {Dalv }} / \mathrm{V}_{\mathrm{T}}$ & 0.93 & 0.87 & 0.00003 \\
& $\mathrm{~V}_{\text {Dphys }}$ & 0.74 & 0.55 & $0.009 \mathrm{I}$ \\
& $\mathrm{V}_{\text {Dphys }} \mathrm{V}_{\mathrm{T}}$ & $0.8 \mathrm{I}$ & 0.66 & 0.0024 \\
\hline
\end{tabular}

Abbreviations: $\mathrm{V}_{\text {Dalv }}$, alveolar dead space; $\mathrm{V}_{\text {Dalv }} / \mathrm{V}_{\mathrm{T}}$, alveolar dead space/tidal volume ratio; $V_{\text {Dphys }}$, physiologic dead space; $V_{\text {Dphys }} / V_{T}$, physiologic dead space/tidal volume ratio.

intrapulmonary right-to-left shunting, venous admixture, and impaired lung mechanics. ${ }^{29,32,33}$

Following lavage, alveoli become unstable and tend to collapse abruptly during expiration when the transalveolar pressure decreases below critical closing pressure. ${ }^{34}$ In the presence of continuing capillary perfusion of these unstable gas-exchange units, venous admixture (intrapulmonary shunt) increases. Surfactant deficiency induced by BAL elevates alveolar and physiological dead space, ${ }^{25}$ lowers mean lung volume above residual volume, ${ }^{35}$ decreases arterial $\mathrm{PaO}_{2}$, increases arterial $\mathrm{PaCO}_{2}$, decreases the a/A ratio, elevates pulmonary arterial pressure ${ }^{36}$ elevates systolic right ventricular pressure, ${ }^{23}$ increases right-to-left shunting/venous admixture, ${ }^{23,25}$ and increases perfusion of low ventilationperfusion regions. ${ }^{37}$ In the adult rabbit, whole-lung lavage increases $\mathrm{V}_{\text {Dalv }}$ almost fivefold and the $\mathrm{V}_{\text {Dalv }} / \mathrm{V}_{\mathrm{T}}$ ratio from zero to one-third of $\mathrm{V}_{\mathrm{T}}{ }^{25}$ If not treated with surfactant, the majority of lavaged rabbits deteriorate over 1-2 hours in regard to static lung compliance and oxygenation status. ${ }^{38}$ Like others, we found that lavage increased the alveolar and physiologic dead space/ $\mathrm{V}_{\mathrm{T}}$ ratio. ${ }^{25}$ The increase in physiological dead space would indicate that less of the tidal volume is involved in gas exchange. In addition we found a good correlation between alveolar and physiological dead space/ $\mathrm{V}_{\mathrm{T}}$ ratio and arterial end-tidal $\mathrm{PCO}_{2}$ differences for the $\mathrm{S}$ and $\mathrm{GE}_{\mathrm{Ca}}^{+2}$ groups, but not for the GE group (Table 3 ). In general, higher arterial end-tidal differences were based on an increase in dead space $/ \mathrm{V}_{\mathrm{T}}$ ratio. The alveolar dead space/ $\mathrm{V}_{\mathrm{T}}$ ratio has previously been shown to be the best indicator of ventilation disorders and to indicate right-to-left shunt, based mainly on atelectasis. ${ }^{25}$ Regions of high ventilation- perfusion ratios contribute to dead space, and the $\mathrm{P}(\mathrm{a}-\mathrm{A}) \mathrm{CO}_{2}$ value is accepted as an indicator of high ventilation-perfusion lung regions. ${ }^{39}$ Within 3 hours following surfactant instillation, we found a significant and sustained improvement in oxygenation in S-treated animals compared to the other groups. Concurrent with the improved oxygenation status, we observed a significant decrease in the $\mathrm{P}(\mathrm{a}-\mathrm{et}) \mathrm{CO}_{2}$ in the $\mathrm{S}$ and $\mathrm{GE}_{\mathrm{Ca}}{ }^{2+}$ groups, which led us to conclude that $\mathrm{S}$ clearly improved (decreased) high ventilation-perfusion regions, more so than was the case in the other two groups. ${ }^{39}$

An increase in oxygenation following instillation of surfactant is largely due to an increase in lung volume, more specifically the functional residual capacity (FRC), ${ }^{40,41}$ and it is reasoned that the increase in FRC is due to stabilization of already open but underventilated air spaces and recruitment of atelectatic gas-exchange units. In the presence of surfactant, the relative contribution of these two mechanisms may depend on ventilator settings, ie, employment of PEEP, mean airway pressure, and other recruitment maneuvers. In the present study, PEEP and mean airway pressures did not differ between groups. We did not measure FRC and could not standardize dynamic compliance for changes in FRC. Did we overventilate open lung units? In that regard, we checked and reviewed the quantitative change in compliance during the last $20 \%$ of inspiration $\left(\mathrm{C}_{20}\right)$ and compared this value to the total compliance value for the entire breath (C) using the ratio $\mathrm{C}_{20} / \mathrm{C}$. ${ }^{42}$ In patients with overdistention, the $\mathrm{C}_{20} / \mathrm{C}$ values decrease below 0.8 . Reviewing the same in our groups showed that no rabbits were overventilated for any significant period of time. However, the 300-minute values were significantly lower than the 15-minute values, correlating with higher and lower compliance values at the corresponding time points, respectively. This correlation suggests that some degree of overventilation was taking place that influenced dynamic compliance values towards the end of the study. Another factor that has to be considered in regard to changes observed in oxygenation and shunt over time is lavage-induced pulmonary vascular constriction. In addition to surfactant deficiency, largevolume saline lavage $(>20 \mathrm{~mL} / \mathrm{kg})$ has previously been shown to increase intrapulmonary right-to-left shunt, with a simultaneous increase in systolic right ventricular pressure. ${ }^{23}$ We speculate that a raised systolic right ventricular pressure reflects a raised pulmonary vascular resistance, which could have adversely affected cardiac output, with lowered saturation of mixed venous blood. We substituted the true calculation of shunt (which requires measuring of mixed venous blood) with the calculated shunt ${ }^{29}$ whilst 
animals were receiving $100 \%$ oxygen. Several variables may affect this calculation. In this regard, the effect of $\mathrm{FiO}_{2}$ was taken out of the equation, since $\mathrm{FiO}_{2}$ remained at 1.0. In regard to possible hypoventilation, we measured serial $\mathrm{PaCO}_{2}$ levels and attempted to deliver a constant tidal volume and minute ventilation throughout the study period. Furthermore, PEEP was kept constant, with intermittent checks for inadvertent PEEP, and blood pressure and pulse rates and rectal temperature did not vary between groups. We were able to show that the intrapulmonary right-to-left shunt increased from baseline to approximately $45 \%$ after lavage, thereafter significantly decreasing over time following surfactant instillation. The initial postlavage value was very similar to values obtained by Boynton et a ${ }^{35}$ who determined venous admixture and found that the percentage venous admixture varied between $35 \%$ and $55 \%$ at a mean airway pressure between 10 and $15 \mathrm{cmH}_{2} \mathrm{O}$, respectively. We therefore conclude that in the S-treated group, mean airway pressure changes possibly altered lung volumes and/ or redistributed ventilation within alveoli already ventilated, which affected shunt values.

Since we did not measure pulmonary vascular resistance, mixed venous oxygen content, or assessed lung volume, we speculate that the decrease in shunt fraction after surfactant instillation could be related to one or more of the following: shunting of blood from poorly to better-ventilated lung regions (improved ventilation-perfusion matching), a decrease in pulmonary vascular resistance (relief of hypoxic vasoconstriction) in the open but not hypoventilated compartment, or lung-volume recruitment. Similar to our study, Wenzel et $\mathrm{al}^{25}$ found that protein-containing bovine surfactant replacement after BAL improved gas exchange but failed to restore the lung to its prelavage condition, which they concluded indicates that exogenous surfactant affects only partly the recruitment of the atelectatic areas.

A criticism of the present study is the lack of lung histology, and this would have to be addressed in future studies involving animal models treated with newer synthetic surfactants. A paucity of studies in this regard, especially following surfactant treatment after saline lavage of adult rabbits, was noted. Repetitive total lung lavage in adult rabbits leads to a reproducible severe surfactant-deficient lung injury. The most prominent light-microscopy findings include varying degrees of atelectasis, edema, intra-alveolar protein leak, hyaline membrane formation, congestion, patchy intraalveolar hemorrhage, lymphatic dilatation, and infiltration of neutrophils associated with peripheral neutropenia. After treatment with surfactant, these changes are still evident, albeit more marked in placebo controls..$^{12,43,44}$ In addition, some authors have described better aeration of alveoli, measured by volume density, in surfactant-treated groups. ${ }^{43}$

Poly-L-lysine can exist in a variety of conformations, depending on the degree of ionization of the amino groups in the side chains, temperature, and salt concentration. When we examined the circular dichroism spectrum of the poly-L-lysine-poly-L-glutamic acid complex, it showed a maxima at $218 \mathrm{~nm}$, indicative that the mixture exists in the native random-coil conformation (JM van Zyl, unpublished results, 2000). This is in accordance with the findings of Chittchang et a ${ }^{45}$ who found that the random coil is the native secondary structure of polylysine. Although hydrophobicity of poly-L-lysine significantly increases in the order; random coil $<\alpha$-helix $<\beta$-sheet conformers, ${ }^{46}$ we know from our previous experience that complexes of poly-L-lysine and poly-L-glutamic acid have a degree of hydrophobicity, as we have shown that conjugates of polylysine electrostatically bind to DNA and make good cell-transfecting agents. ${ }^{47}$ Moreover, poly-L-lysine adopts a $\beta$-sheet conformation from the random coil during interaction with phospholipids. ${ }^{48}$ On the other hand, the random coil (disordered state) of a polymer mixture will favor the exposure of the basic charged surface groups on the lysine side chains whereby the peptide could interact flexibly with other molecules to perform a functional role in cell membranes. The overall effect could then possibly be electrostatic binding to phospholipid monolayers. ${ }^{49}$ With regards to SP-B, the $\alpha$-helical and $\beta$-sheet secondary structure is proposed to penetrate into the lipid acyl chains of the phospholipid membrane lining in alveolar walls, thus providing stability and preventing atelectatic collapse. ${ }^{50} \mathrm{We}$ therefore make the assumption that the charged amino groups of poly-L-lysine in our S preparation could also possibly interact with the phospholipid bilayer and thus could mimic some structural and/or functional properties of SP-B. On the other hand, as positive charges are important for maintaining the structure and function of SP-C, ${ }^{51}$ it can alternatively be argued that the overall positive character of poly-L-lysine residues in $\mathrm{S}$ could then rather contribute to the mimicking of SP-C structural and/or functional properties.

To conclude, in keeping with the finding of similar experimental and human studies, the best indicator of the efficacy of the surfactant was the changes observed in systemic oxygenation over time. In addition to this, the statistically significant decrease in pulmonary shunt found for the S-treated group of animals suggests that the present phospholipid mixture formulated with poly-L-lysine-polyL-glutamic acid as a complex (cationic and hydrophobic) 
improves oxygenation in the rabbit model of acute lung injury/surfactant depletion.

\section{Disclosure}

Johan Smith, Johann van Zyl and Arthur Hawtrey are codesigners and developers of the peptide-containing synthetic surfactant. The surfactant has been patented by InnovUS (Stellenbosch University).

\section{References}

1. Soll R. Natural surfactant extract versus synthetic surfactant for neonatal respiratory distress syndrome. Cochrane Database Syst Rev. 2001;2:CD000144.

2. Halliday HL, Speer CP. Strategies for surfactant therapy in established neonatal respiratory distress syndrome. In: Taeusch HW, editor. Surfactant Therapy for Lung Disease (Lung Biology in Health and Disease). New York: Marcell Dekker; 1995:443-459.

3. King RJ, Klass DJ, Gikas EG, Clements JA. Isolation of apoproteins from canine surface active material. Am J Physiol. 1973;224(4):788-795.

4. Jeffrey A, Whitsett MD, Weaver TE. Hydrophobic surfactant proteins in lung function and disease. N Engl J Med. 2002;347(26):2141-2148.

5. McCormack MD. Molecular biology of surfactant apoprotreins. Semin Respir Crit Care Med. 1995;16(1):29-38.

6. Baatz JE, Bruno MD, Ciraolo PJ, et al. Utilization of modified surfactant-associated protein B for delivery of DNA to airway cells in culture. Proc Natl Acad Sci U SA. 1994;91(7):2547-2551.

7. Strayer DS, Robertson B. Surfactant as an immunogen: implications for therapy of respiratory distress syndrome. Acta Paediatr. 1992;81(5): 446-447.

8. Cochrane CG, Revak SD, Merrit, TA, et al. The efficacy and safety of KL4-surfactant in preterm infants with respiratory distress syndrome. Am J Respir Crit Care Med. 1996;153(1):404-410.

9. Ma J, Koppenol S, Yu II, Zografi G. Effects of a cationic and hydrophobic peptide, KL4, on model surfactant lipid monolayers. Biophys $J$ 1998;74(4):899-907.

10. Revak SD, Merritt TA, Cochrane CG, et al. Efficacy of synthetic peptide-containing surfactant in the treatment of respiratory distress syndrome in preterm infant rhesus monkeys. Pediatr Res. 1996;39(4 Pt 1): 715-724.

11. Durand DJ, Clyman RI, Heymann MA, et al. Effects of a protein-free, synthetic surfactant on survival and pulmonary function in preterm lambs. J Pediatr. 1985;107(5):775-780.

12. Smith J, Hoal EG, Coetzee AR, et al. Addition of trehalose to dipalmitoyl phosphatidylcholine, hexadecanol and tyloxapol improves oxygenation in surfactant-deficient rabbits. S Afr J Sci. 2006;102(3-4):155-161.

13. Smith J. A comparison of Synthetic Surfactants. Evaluation of a Novel Surfactant (1,2-Dipalmitoyl-sn-Phosphatidylcholine and Trehalose $\left[\mathrm{C}_{12} \mathrm{H}_{22} \mathrm{O}_{11}\right]$ ) and Comparison with Other Synthetic Formulations [thesis]. Cape Town: Stellenbosch University; 2002.

14. Notter RH, Finkelstein JN, Taubold RD. Comparative adsorption of natural lung surfactant, extracted phospholipids, and artificial phospholipid mixtures to the air-water interface. Chem Phys Lipids. 1983;33(1): 67-80.

15. Banerjee R, Bellare J. Effect of calcium on the surface properties of phospholipid monolayers with respect to surfactant formulations in respiratory distress syndrome. Biomed Mater Eng. 2001;11(1): 43-53.

16. Benson BJ, Williams MC, Sueishi K, Goerke J, Sargeant T. Role of calcium in the structure and function of pulmonary surfactant. Biochim Biophys Acta. 1984;793(1):18-27.

17. Touchstone JC, Chen JC, Beaver KM. Improved separation of phospholipids in thin layer chromatography. Lipids. 1979;15(1): $61-62$.
18. McGrath JC, MacKenzie JE, Millar RA. Circulatory responses to ketamine: dependence on respiratory pattern and background anaesthesia in the rabbit. Br J Anaesth. 1975;47(11):1149-1155.

19. Kozma C, Macklin W, Cummins LM, Mauer R. The anatomy, physiology and biochemistry of the rabbit. In: Weisbroth SH, Flatt RE, Kraus AL, editors. The Biology of the Laboratory Rabbit. New York: Academic Press; 1974:50-72.

20. Rider ED, Ikegami M, Whitsett JA, Hull W, Absolom D, Jobe AH Treatment responses to surfactants containing natural surfactant proteins in preterm rabbits. Am Rev Respir Dis. 1993;147(3):669-676.

21. Dizon-Co L, Ikegami M, Ueda T, et al. In vivo function of surfactants containing phosphatidylcholine analogs. Am J Respir Crit Care Med. 1994;150(10):918-923.

22. Zhu GFA, Sun B, Niu SF, Cai YY, Lin K, Lindwall R. Combined surfactant therapy and inhaled nitric oxide in rabbits with oleic acidinduced acute respiratory distress syndrome. Am J Respir Crit Care Med. 1998;158(2):437-443.

23. Krause MF, Lienhart HG, Haberstroh J, Hoehn T, Schulte-Monting J, Leititis JU. Effect of inhaled nitric oxide on intrapulmonary right-toleft-shunting in two rabbit models of saline lavage induced surfactant deficiency and meconium instillation. Eur J Pediatr. 1998;157(5): $410-415$.

24. Rimensberger PC, Cox PN, Frndova H, Bryan AC. The open lung during small tidal volume ventilation: concepts of recruitment and "optimal" positive end-expiratory pressure. Crit Care Med. 1999;27(9): 1946-1952.

25. Wenzel U, Rudiger M, Wagner H, Wauer RR. Utility of deadspace and capnometry measurements in determination of surfactant efficacy in surfactant depleted lungs. Crit Care Med. 1999;27(5):946-953.

26. Kerr CL, Ito Y, Manwell SEE, et al. Effects of surfactant distribution and ventilation strategies on efficacy of exogenous surfactant. $J \mathrm{Appl}$ Physiol. 1998;85(2):676-684.

27. Gommers D, Hartog A, van 't Veen A, Lachmann B. Improved oxygenation by nitric oxide is enhanced by prior lung reaeration with surfactant, rather than positive end-expiratory pressure, in lung-lavaged rabbits. Crit Care Med. 1997;25(11):1868-1873.

28. Lachmann B, Robertson B, Vogel J. In vivo lung lavage as an experimental model of respiratory distress syndrome. Acta Anaesth Scand. 1980;24(3):231-236.

29. Coetzee AR. Hipoksie: die agtergrond vir die interpretasie van moontlike oorsake. [Hypoxia: the background to the interpretation of possible causes]. S Afr J Crit Care. 1987;3(2):28-31. Afrikaans.

30. Pinheiro J, Bates D, DebRoy S, Sarkar DR. The R Development Core Team nlme. Linear and nonlinear mixed effects models. 2011. $\mathrm{R}$ package version 3.1-102.

31. Maritz JS, Lombard CJ, Morell CH. Exact group comparison using irregular longitudinal data. Appl Stat. 1998;47(3):351-360.

32. Kobayashi T, Kataoka H, Ueda T, Murakami S, Takada Y, Kobubo M. Effects of surfactant supplement and end-expiratory pressure in lunglavaged rabbits. J Appl Physiol. 1984;57(4):995-1001.

33. Mcculloch PR, Forkert PG, Froese AB. Lung volume maintenance prevents lung injury during high frequency oscillatory ventilation in surfactant-deficient rabbits. Am Rev Respir Dis. 1988;137(5):1185-1192.

34. Cotton RB. A model of the effect of surfactant treatment on gas exchange in hyaline membrane disease. Semin Perinatol. 1994;18(1): $19-22$.

35. Boynton BR, Villanueva D, Hammond MD, Vreeland PN, Buckley B, Frantz ID. Effect of mean airway pressure on gas exchange during high-frequency oscillatory ventilation. J Appl Physiol. 1991;70(2): 701-707.

36. Burger R, Bryan AC. Pulmonary hypertension after postlavage lung injury in rabbits: possible role of polymorphonuclear leukocytes. J Appl Physiol. 1991;71(5):1990-1995.

37. Schermuly RT, Gunther A, Weissmann N, et al. Differential impact of ultrasonically nebulized versus tracheal-instilled surfactant on ventilation-perfusion (VA/Q) mismatch in a model of acute lung injury. Am J Respir Crit Care Med. 2000;161(1):152-159. 
38. Makhoul IR, Kugelman A, Garg M, Berkeland JE, Lew CD, Bui K. Intratracheal pulmonary ventilation versus conventional mechanical ventilation in a rabbit model of surfactant deficiency. Pediatr Res. 1995;38(6):878-885.

39. Billman D, Nicks J, Schumacher R. Exosurf rescue surfactant improves high ventilation-perfusion mismatch in respiratory distress syndrome. Pediatr Pulmonol. 1994;18(5):279-283.

40. Gommers D, Vilstrup C, Bos JAH, et al. Exogenous surfactant therapy increases static lung compliance, and cannot be assessed by measurements of dynamic compliance alone. Crit Care Med. 1993;21(4): $567-574$.

41. Cotton RB, Olsson T, Law AB, et al. The physiological effects of surfactant treatment on gas exchange in newborn premature infants with hyaline membrane disease. Pediatr Res. 1993;34(4):495-501.

42. Fisher JB, Mammel MC, Coleman JM, Bing DR, Boros SJ. Identifying lung overdistention during mechanical ventilation by using volumepressure loops. Pediatr Pulmonol. 1988;5(1):10-14.

43. Zhou BH, Sun B, Zhou ZH, Zhu LW, Fan SZ, Lindwall R. Comparison of effects of surfactant and inhaled nitric oxide in rabbits with surfactantdepleted respiratory failure. Zhongguo Yao Li Xие Bao. 1999;20(8): 691-695.

44. Burger R, Fung D, Bryan ACJ. Lung injury in a surfactant-deficient lung is modified by indomethacin. J Appl Physiol. 1990;69(6):2067-2071.
45. Chittchang M, Alur HH, Mitra AK, Johnston TP. Poly(L-lysine) as a model drug macromolecule with which to investigate secondary structure and membrane transport, part 1: physicochemical and stability studies. J Pharm Pharmacol. 2001;54(3):315-323.

46. Gray RA, Vander Velde DG, Burke CJ, Manning MC, Middaugh CR, Borchardt RT. Delta-sleep-inducing peptide: solution conformational studies of a membrane-permeable peptide. Biochemistry. 1994;33(6): 1323-1331.

47. Larson G, Pieterse A, Quick G, Van der Bijl P, Van Zyl J, Hawtrey A. Development of a reproducible procedure for plasmid DNA encapsulation by red blood cell ghosts. Biodrugs. 2004;18(3):189-198.

48. Fukushima K, Sakamoto T, Tsuji J, Kondo K, Shimozawa R. The transition of $\alpha$-helix to $\beta$-structure of poly(L-lysine) induced by phosphatidic acid vesicles and its kinetics at alkaline pH. Biochim Biophys Acta. 1994;1191(1):133-140.

49. Carrier D, Dufourcq J, Faucon JF, Pézolet M. A fluorescence investigation of effects of polylysine on dipalmitoylphosphatidylglycerol bilayers. Biochim Biophys Acta. 1985;820(1):131-139.

50. Whitsett JA, Weaver TE. Hydrophobic surfactant proteins in lung function and disease. $N$ Engl J Med. 2002;347(26):2141-2148.

51. Creuwels LAJM, Boer EH, Demel RA, Van Golde LMG, Haagsman HP. Neutralization of the positive charge of SP-C: effects in structure and function. J Biol Chem. 1995;270(27):16225-16229.
Drug Design, Development and Therapy

\section{Publish your work in this journal}

Drug Design, Development and Therapy is an international, peerreviewed open-access journal that spans the spectrum of drug design and development through to clinical applications. Clinical outcomes, patient safety, and programs for the development and effective, safe, and sustained use of medicines are a feature of the journal, which

\section{Dovepress}

has also been accepted for indexing on PubMed Central. The manuscript management system is completely online and includes a very quick and fair peer-review system, which is all easy to use. Visit http://www.dovepress.com/testimonials.php to read real quotes from published authors.

Submit your manuscript here: http://www.dovepress.com/drug-design-development-and-therapy-journal 